\title{
Darkening of the Greenland Ice Sheet: Fungal Abundance and Diversity Are Associated With Algal Bloom
}

\section{Laura Perini', Cene Gostinčar1,2, Alexandre Magno Anesio ${ }^{3,4}$, Christopher Williamson ${ }^{3}$, Martyn Tranter ${ }^{3}$ and Nina Gunde-Cimerman ${ }^{1 *}$}

${ }^{1}$ Department of Biology, Biotechnical Faculty, University of Ljubljana, Ljubljana, Slovenia, ${ }^{2}$ Department of Molecular and Biomedical Sciences, Jožef Stefan Institute, Ljubljana, Slovenia, ${ }^{3}$ Bristol Glaciology Centre, School of Geographical Sciences, University of Bristol, Bristol, United Kingdom, ${ }^{4}$ Department of Environmental Science, Aarhus University, Roskilde, Denmark

Recent studies have highlighted the importance of ice-algal blooms in driving darkening and therefore surface melt of the Greenland Ice Sheet (GrIS). However, the contribution of fungal and bacterial communities to this microbially driven albedo reduction remains unconstrained. To address this significant knowledge gap, fungi were isolated from key GrlS surface habitats (surface ice containing varying abundance of ice algae, supraglacial water, cryoconite holes, and snow), and a combination of cultivation and sequencing methods utilized to characterize the algal-associated fungal and bacterial diversity and abundance. Six hundred and ninety-seven taxa of fungi were obtained by amplicon sequencing and more than 200 fungal cultures belonging to 46 different species were isolated through cultivation approaches. Basidiomycota dominated in surface ice and water samples, and Ascomycota in snow samples. Amplicon sequencing revealed that bacteria were characterized by a higher diversity (883 taxa detected). Results from cultivation as well as ergosterol analyses suggested that surface ice dominated by ice algae and cryoconite holes supported the highest fungal biomass $\left(10^{4}-10^{5} \mathrm{CFU} / 100 \mathrm{ml}\right)$ and that many fungal taxa recognized as endophytes and plant pathogens were associated with dark ice characterized by a high abundance of ice algae. This paper significantly advances this field of research by investigating for the first time the fungal abundance and diversity associated with algal blooms causing the darkening of the GrIS. There is a strong association between the abundance and diversity of fungal species and the blooming of algae on the surface ice of the Greenland Ice Sheet.

Keywords: fungi, bacteria, Greenland Ice Sheet, dark ice, ice algae, NGS, microbial diversity, albedo effect

\section{INTRODUCTION}

The Greenland Ice Sheet (GrIS) is the largest ice mass of the northern hemisphere, covering an area of around 1.7 million $\mathrm{km}^{2}$ and comprising circa $11 \%$ of the Earth's cryosphere (Abdalati and Steffen, 1995). Recently recognized as one of the Earth's biomes (Anesio and Laybourn-Parry, 2012), the GrIS is dominated by various microbial communities that inhabit a range of surface environments, 
including snow, ice, supraglacial water and cryoconite holes formed via a bio-cryomorphological process (Cook et al., 2015). Significant research is currently focused on ice algal taxa belonging to the class Zygnematophyceae (Streptophyta) that are able to survive in surface ice environments (Remias et al., 2009, 2012a,b, Williamson et al., 2018). These algae are the closest living relatives of land plants (de Vries et al., 2016; de Vries and Archibald, 2018) and can form extensive blooms within surface ice during summer ablation seasons (Yallop et al., 2012; Stibal et al., 2017; Williamson et al., 2018). Such algal blooms are typically dominated by Ancylonema nordenskiöldii and Mesotaenium berggrenii (Williamson et al., 2018) and, due to the high abundance of cells apparent $\left(\sim 10^{4}\right.$ cells $\mathrm{ml}^{-1}$ ) and the significant pigmentation of ice algal taxa (Remias et al., 2009, 2012a,b, Williamson et al., 2018), impart a conspicuous brownish-grayish tint to the supraglacial ice, which is subsequently referred to as dark or dirty ice (Williamson et al., 2018). Together with wind-borne debris, ice algal blooms thus serve to reduce GrIS surface reflectance (albedo) (Yallop et al., 2012; Musilova et al., 2017; Stibal et al., 2017; Ryan et al., 2018) and consequently, increase surface melt (van den Broeke et al., 2017; Ryan et al., 2018). Increased surface melt in turn supplies more melt water to the microorganisms, creating a positive feedback loop between their growth and melting of the GrIS.

To-date, the majority of microbial studies conducted on GrIS supraglacial habitats have focused on ice algal blooms (Yallop et al., 2012; Stibal et al., 2017; Williamson et al., 2018), and the abundance and diversity of bacterial communities on ice and cryoconites (Cameron et al., 2015a,b; Musilova et al., 2015; Stibal et al., 2015). However, to our knowledge, no studies have addressed the diversity or abundance of GrIS fungal communities, or their potential associations with the ice algal community. Fungi are otherwise recognized as an important part of the Arctic's microbial biodiversity, with over 4,000 species described to-date (Dahlberg et al., 2013). Fungal communities are known to be essential for the functioning of Arctic ecosystems given their saprotrophic roles (Dahlberg et al., 2013), and in biogeochemical cycling processes (Gadd, 2007). Fungi also influence the occurrence of other microorganisms through different types of interactions, beneficial as well as detrimental (Meltofte et al., 2013; Rämä et al., 2017). However, the fungal impact on the biogeochemical processes within different GrIS habitats remain underestimated. In Greenland, investigations of fungi have been limited to the studies of their occurrence, distribution and ecology in soil and in association with lichens (Alstrup et al., 2000; Zoller and Lutzoni, 2003; Kristinsson et al., 2010; Timling and Taylor, 2012; Timling et al., 2014), with no data available on fungi proliferating and interacting in water-icebased environments.

The aim of this study was therefore to provide the first comprehensive analysis of the fungal diversity from the surface of the GrIS. To this end, a combination of culturing and ITS amplicon sequencing was applied to five different GrIS surface habitats: snow, supraglacial water, sediment and water from cryoconite holes, and surface ice containing a low and high abundance of ice algae. Bacterial diversity was determined in parallel by cultivation and amplicon sequencing techniques.
Special consideration was given to the comparison between the dark ice and other habitats.

\section{MATERIALS AND METHODS}

\section{Site and Sampling Description}

Two sampling campaigns were conducted during the 2016 (JulyAugust) and 2017 (June-July) melt seasons in the south-western ablation zone of the GrIS, covering in 2 years an entire ablation season: from snow to the end of melt. The sampling site was located $\sim 60 \mathrm{~km}(67.078694,-49.341583)$ east of Kangerlussuaq, and was situated within the 'dark zone', a region running along the western edge of the GrIS that is characterized by particularly low albedo and extensive ice algal blooms during summer melt seasons (Yallop et al., 2012; Stibal et al., 2017; Williamson et al., 2018) (Figure 1). The samples were collected using clean, disposable nitrile gloves, and were transferred into sterile Whirl$P_{a k^{\circledR}}$ plastic bags. Samples were collected from supraglacial water, sediment and water from cryoconite holes ("slurry"), dispersed cryoconite (only in 2016), fresh snow (only in 2017), surface ice with high abundance of ice algae $\left(10^{4}\right.$ cells $\left.\mathrm{ml}^{-1}\right)$ - hereafter referred to as dark ice, and with low algal abundance $\left(10^{1}\right.$ cells $\mathrm{ml}^{-1}$ ), referred to as clear ice.

\section{Cultivation-Based Fungal and Bacterial Diversity Analysis}

Initial sampling to investigate the presence/absence of surface fungal communities was performed in 2016 of which cultivation and NGS results will be shown, with more comprehensive sampling and analyses performed in 2017 given our initial results. All samples, except supraglacial water and slurry from cryoconite holes, were melted aseptically in situ at site temperature and due to the unknown fungal abundances and in order to obtain single colony forming units, aliquots of $10 \mathrm{ml}$ and $100 \mathrm{ml}$ were filtered through Milli-pore membrane filters $(0.45 \mu \mathrm{m}$ pore size $)$ in duplicate. Filters were placed on two enumeration and four different selective agar media with either low nutrient content (used only in 2017 sampling) or with low water activity $\left(\mathrm{a}_{\mathrm{w}}\right)$. $100 \mu \mathrm{l}$ of the original sample from all environments were directly applied on all media and dispersed with a sterile Drigalski spatula. Media used included DRBC - a general-purpose enumeration medium $\left(\mathrm{a}_{\mathrm{w}}=1\right)$ (King et al., 1979); DG-18 - a medium for detection of moderate xerophiles $\left(a_{\mathrm{w}}=0.946\right)$ (Hocking and Pittx, 1980); MY10-12 - a medium for the isolation of xero- and halo-tolerant fungi with $10 \%$ glucose and $12 \% \mathrm{NaCl}$ $\left(\mathrm{a}_{\mathrm{w}}=0.880\right)$ (Pitt and Hocking, 2009); R2A - a low nutrient enumeration medium for heterotrophic microorganisms (both bacteria and fungi), $\left(\mathrm{a}_{\mathrm{w}}=1\right)$, (Reasoner and Geldreichm, 1985); and SNA and MM - two nutrient-poor media for the isolation of oligotrophic fungi $\left(\mathrm{a}_{\mathrm{w}}=1\right)$ used in 2017 sampling (Nirenberg, 1981; de Vries et al., 2004). For the prevention of bacterial growth, chloramphenicol $(50 \mathrm{mg} / \mathrm{l})$ was added to all media, except for R2A agar. Plates, with a total of seven plates of each medium for each sample, were incubated at the sampling site at temperatures varying from approximately $-2^{\circ} \mathrm{C}$ to $+10^{\circ} \mathrm{C}$ for 1 week, and at $10^{\circ} \mathrm{C}$ for $4-12$ weeks at the University of Ljubljana, where 

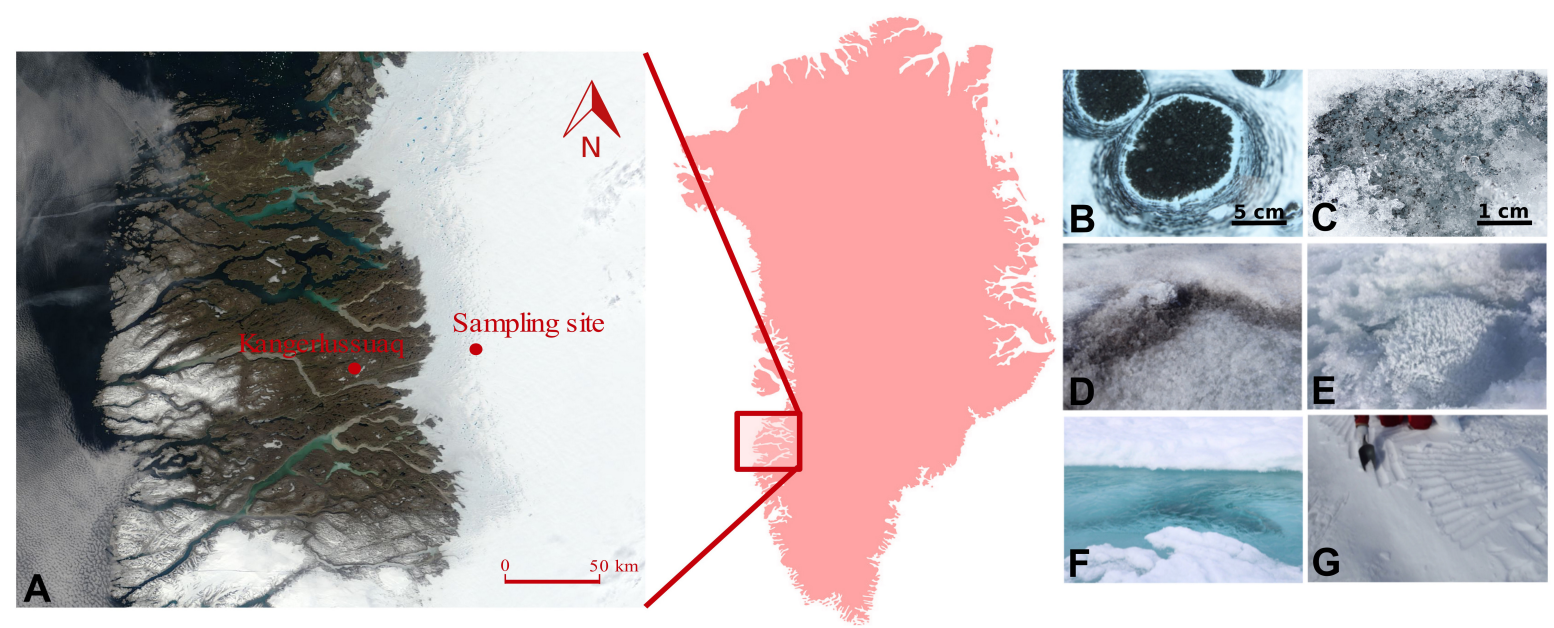

FIGURE 1 | Location of the sampling site on the south-western Greenland Ice Sheet (A), with insert showing the relative position of the sampling region within Greenland. Map is acquired as an image from Modis Satellite. Images show the type of samples collected: cryoconite holes (B), dispersed cryoconite (C), dark ice (D), clear ice (E), supraglacial water (F), and fresh snow (G).

subsequent analyses were carried out. For every medium, the average number of colony forming units (CFU/100 ml) was visually determined.

\section{Fungal and Bacterial Identification}

DNA was extracted from pure fungal and bacterial cultures up to 1 week after incubation on a malt extract agar (MEA) and R2A media, respectively. DNA from filamentous fungi was extracted by mechanical lysis of approximately $\mathrm{cm}^{2}$ of mycelium according to van den Ende and de Hoog (1999). For yeast-like and bacterial strains, DNA was extracted using PrepMan Ultra reagent (Applied Biosystems, Foster City, CA, United States) according to the manufacturer instructions. For filamentous fungi a fragment of rDNA including ITS region 1, 5.8S rDNA and ITS region 2 (ITS) was amplified using ITS5 and ITS4 primers (White et al., 1990). Polymerase chain reactions (PCRs) were performed using Thermo Scientific Taq DNA Polymerase according to manufacturer's protocol. Reactions were run in a PCR Mastercycler Ep Gradient (Eppendorf) with an initial denaturation of $2 \mathrm{~min}$ at $95^{\circ} \mathrm{C}$, followed by 30 cycles of denaturation at $95^{\circ} \mathrm{C}$ for $45 \mathrm{~s}$, annealing at $54^{\circ} \mathrm{C}$ for $30 \mathrm{~s}$, and elongation at $72^{\circ} \mathrm{C}$ for $2 \mathrm{~min}$, with a final elongation at $72^{\circ} \mathrm{C}$ for $4 \mathrm{~min}$. For identification of Penicillium strains, the partial $\beta$-tubulin gene (benA) was amplified and sequenced with Ben2f and Bt2b primers (Glass and Donaldson, 1995). Initial denaturation at $95^{\circ} \mathrm{C}$ for $1 \mathrm{~min}$ was followed by 35 cycles of denaturation at $95^{\circ} \mathrm{C}$ for $30 \mathrm{~s}$, annealing at $53^{\circ} \mathrm{C}$ for $30 \mathrm{~s}$, and elongation at $72^{\circ} \mathrm{C}$ for $1 \mathrm{~min}$. Final elongation was at $72^{\circ} \mathrm{C}$ for $10 \mathrm{~min}$. Cladosporium strains were identified using partial actin (act) sequences, amplified with ACT-512F and ACT-783R primers (Carbone and Kohn, 1999). Initial denaturation at $94^{\circ} \mathrm{C}$ for $5 \mathrm{~min}$ was followed by 45 cycles of denaturation at $94^{\circ} \mathrm{C}$ for $45 \mathrm{~s}$, annealing at $52^{\circ} \mathrm{C}$ for $30 \mathrm{~s}$ and elongation at $72^{\circ} \mathrm{C}$ for $90 \mathrm{~s}$. Final elongation was at $72^{\circ} \mathrm{C}$ for $5 \mathrm{~min}$. For yeasts domains D1 and D2 of LSU rDNA gene were amplified using NL1 and NL4 primers (Boekhout and Kurtzman, 1996). Initial denaturation at $95^{\circ} \mathrm{C}$ for $5 \mathrm{~min}$ was followed by 30 cycles of denaturation at $95^{\circ} \mathrm{C}$ for $45 \mathrm{~s}$, annealing at $54^{\circ} \mathrm{C}$ for $30 \mathrm{~s}$ and elongation at $72^{\circ} \mathrm{C}$ for $2 \mathrm{~min}$. Final elongation was at $72^{\circ} \mathrm{C}$ for $4 \mathrm{~min}$. For bacteria $16 \mathrm{~S}$ rRNA gene was amplified with $27 \mathrm{f}$-lane and 1492R primers (Lane, 1991) and a touchdown program. Initial denaturation at $95^{\circ} \mathrm{C}$ for 5 min was followed by five cycles of denaturation at $95^{\circ} \mathrm{C}$ for $30 \mathrm{~s}$, annealing at $60^{\circ} \mathrm{C}$ for $30 \mathrm{~s}$ and elongation at $72^{\circ} \mathrm{C}$ for $1 \mathrm{~min}$; five cycles of denaturation at $95^{\circ} \mathrm{C}$ for $30 \mathrm{~s}$, annealing at $55^{\circ} \mathrm{C}$ for $30 \mathrm{~s}$ and elongation at $72^{\circ} \mathrm{C}$ for $1 \mathrm{~min}$; and 30 cycles of denaturation at $95^{\circ} \mathrm{C}$ for $30 \mathrm{~s}$, annealing at $50^{\circ} \mathrm{C}$ for $30 \mathrm{~s}$ and elongation at $72^{\circ} \mathrm{C}$ for $1 \mathrm{~min}$. Final elongation was at $72^{\circ} \mathrm{C}$ for $7 \mathrm{~min}$. The ITS, LSU, benA, act and $16 \mathrm{~S}$ nucleotide sequences were determined by Sanger sequencing, performed by Microsynth AG, Switzerland. The resulting sequences of all the isolates were aligned using MUSCLE software (Edgar, 2004) implemented in MEGA5 package (Tamura et al., 2011) and examined using the BLAST software of the National Centre for Biotechnology Information (NCBI) database (Altschul et al., 1990). Maximum likelihood methods implemented in PhyML 3.0 (Guindon et al., 2010) were used to build phylogenetic trees aligning the resulting sequencing with type and reference sequences in MEGA5 (Tamura et al., 2011) (Supplementary Material). All isolated strains have been deposited in the Ex F Culture Collection of the Infrastructural Centre Mycosmo (MRIC UL) at the Department of Biology, Biotechnical Faculty, University of Ljubljana, Slovenia. LSU, ITS, and $16 \mathrm{~S}$ sequences have been deposited in the GenBank database. GenBank accession numbers are available in the Supplementary Material.

\section{Fungal and Bacterial Diversity Analysis Using Illumina Sequencing}

For 2016 samples, DNA was isolated from filtered biomass (sample volume $750 \mathrm{ml}, 0.45 \mu \mathrm{m}$ pore size, Millipore) of clear ice (C-ice), dark ice (D-ice) and supraglacial water (S-wtr). From 
2017 samples, DNA was isolated from $700 \mathrm{ml}$ of dark ice, $1 \mathrm{~L}$ of clear ice, $2 \mathrm{~L}$ of melted snow (Snow), and $1 \mathrm{~L}$ of supraglacial water. With the exception of supraglacial water from 2016, two biological replicates of each sample were assessed. All filters and $1 \mathrm{~g}$ of cryoconite sediment (Cry) were placed in $1.5 \mathrm{ml}$ microcentrifuge tubes containing RNAlater $^{\circledR}$ (Sigma-Aldrich Company Ltd., United Kingdom) and immediately frozen at $-20^{\circ} \mathrm{C}$ until further analysis in the laboratory. Replicates were treated as independent, with a total of 15 samples labeled with corresponding habitat type followed by the collection year and the number of replicate: C-ice16-1; C-ice16-2; C-ice17-1; C-ice17-2; Cry17-1; Cry17-2; D-ice16-1; D-ice16-2; D-ice17-1; D-ice17-2; S-wtr16-1; S-wtr17-1; S-wtr17-2; Snow17-1; Snow172. DNA was extracted from filters and cryoconite sediment using the PowerWater DNA Isolation Kit (MoBio Laboratories Inc., Carlsbad, CA, United States) and then from the same filters using the PowerLyzer PowerSoil DNA Isolation Kit (MoBio Laboratories Inc., Carlsbad, CA, United States), according to the manufacturer's instructions with a slight modification to increase the DNA yield and quality. To increase efficiency of fungal cells lysis an additional heating incubation at $65^{\circ} \mathrm{C}$ for 10 min was used after adding PW1 solution. DNA from both isolation methods was pooled together and stored at $-80^{\circ} \mathrm{C}$ until PCRs were performed.

For the analysis of fungal diversity, Illumina Miseq V3 (300 bp paired-end) sequencing was carried out on the ITS2 region of the ITS rDNA gene amplified using the primers ITS4-Fun (5' AGCCTCCGCTTATTGATATGCTTAART-3') and 5.8S-Fun (5'-AACTTTYRRCAAYGGATCWCT-3') (Taylor et al., 2016). Amplification was carried out in a PCR Mastercycler Ep Gradient (Eppendorf) with initial denaturation of $2 \mathrm{~min}$ at $98^{\circ} \mathrm{C}$, followed by 20 cycles of $10 \mathrm{~s}$ at $98^{\circ} \mathrm{C}, 25 \mathrm{~s}$ at $54^{\circ} \mathrm{C}$ and of $25 \mathrm{~s}$ at $72^{\circ} \mathrm{C}$, with a final elongation of $7 \mathrm{~min}$ at $72^{\circ} \mathrm{C}$.

For analysis of bacterial diversity, Illumina Miseq V2 (250 bp paired-end) sequencing was carried out on the hypervariable $\mathrm{V} 3$ and V4 regions of the 16S rRNA gene by using the 341F_ill (5' $5^{\prime}$ CCTACGGGNGGCWGCAG-3') and 802R_ill (5' GACTACHVGGGTATCTAATCC- $3^{\prime}$ ) universal bacterial primers (Klindworth et al., 2013). Due to the low amount of DNA, the first step PCRs were performed in Ljubljana lab using Phusion ${ }^{\circledR}$ High-Fidelity DNA Polymerase according to manufacturer's protocol. Reactions were run in a PCR Mastercycler Ep Gradient (Eppendorf) with initial denaturation of $3 \mathrm{~min}$ at $95^{\circ} \mathrm{C}$, followed by 20 cycles of $20 \mathrm{~s}$ at $95^{\circ} \mathrm{C}, 30 \mathrm{~s}$ at $56^{\circ} \mathrm{C}$ and of $30 \mathrm{~s}$ at $72^{\circ} \mathrm{C}$, with a final elongation of $5 \mathrm{~min}$ at $72^{\circ} \mathrm{C}$.

Single-end reads were quality checked and trimmed (minimum quality score 20) and analyzed with QIIME2 2018.8 software package (Quantitative Insights Into Microbial Ecology) (Caporaso et al., 2010). The forward reads data were denoised by DADA2 (Callahan et al., 2016) algorithm using the default parameters, the tree was constructed by FastTree on a mafft alignment and rooted at midpoint and the alpha and beta diversity indices were calculated. For assigning the taxonomy to sequences, the $99 \%$ cut-off GreenGene database (McDonald et al., 2012) was used for training the feature classifier for bacteria, and the dynamically clustered UNITE ITS database (Abarenkov et al., 2010) was used for fungi.
Abundances in each sample were normalized to the number of sequences in the least abundant sample. Due to the high presence of ice algae in dark and clear ice samples, and in order to investigate the bacterial diversity in all samples in a comparable manner, chloroplast sequences were excluded using a taxonomy-based filtering. Shannon index was used to study the alpha diversity. The distance and dissimilarity matrix were determined through Bray-Curtis index to visualize the ordination and clustering of the bacterial and fungal community composition for beta diversity analyses using the principal coordinate analysis (PCoA). Differences in microbial community composition between sample types were assessed by non-parametric permutational analysis of variance (PERMANOVA). All analyses above were performed in QIIME2 2018.8 software package (Quantitative Insights Into Microbial Ecology) (Caporaso et al., 2010).

\section{Ergosterol Quantification}

Quantification of ergosterol as a biomarker molecule for the determination of fungal presence was performed for 2017 environmental samples. Filtration of $500 \mathrm{ml}$ of melted snow and $100 \mathrm{ml}$ of supraglacial water, dark ice, clear ice and cryoconite was performed through Milli-pore membrane filters $(0.45 \mu \mathrm{m}$ pore size) in biological triplicates (in duplicate for snow). Filters were then stored in sterile microcentrifuge tubes containing $1.5 \mathrm{ml}$ of $90 \%$ methanol and frozen in situ until analysis. In the laboratory (Ljubljana), filters and corresponding methanol were transferred to $5 \mathrm{ml}$ sterile centrifuge tubes, and $3 \mathrm{ml}$ of $100 \%$ chloroform was added and vortexed for $15 \mathrm{~min}$ at room temperature. The methanol phase was transferred to a sterile $1.5 \mathrm{ml}$ microcentrifuge tube and dried in a biosafety cabinet overnight. The residues were re-dissolved in $1.5 \mathrm{ml}$ $90 \%$ methanol and vortexed for $5 \mathrm{~min}$ at room temperature. Samples were then filtered through $0.22 \mu \mathrm{m}$ pore size filters and transferred to HPLC tubes. HPLC analyses were performed using Waters HPLC system 2965 (Milford, MA, United States), equipped with a degasser, a quaternary pump, an auto-sampler and 2998 PDA detector set at $280 \mathrm{~nm}$. A Kinetex XB-C18 $(150 \times 4.6 \mathrm{~mm}$, particle size $5 \mu \mathrm{m})$ column (Phenomenex, Torrance, CA, United States) was used. $50 \mu \mathrm{l}$ of each sample was injected. Ergosterol was eluted from the column using an isocratic mobile phase of $100 \%$ methanol and a flow rate of $1.0 \mathrm{ml} / \mathrm{min}$. Before HPLC analysis, standard ergosterol (Sigma, St. Louis, MO, United States) was purified according to Nylund and Wallander (1992). Ergosterol peak was identified by comparison of the retention time and absorbance spectra with the purified ergosterol as standard. Correlation analyses between fungal abundance and ergosterol quantification were performed in $\mathrm{R}$ (R Core Team, 2017).

\section{RESULTS}

\section{Quantification of Cultivable Fungi}

Abundances of cultivable fungi from samples collected in 2017 are presented in Figure 2A. Fungal abundances differed considerably depending on the media used. Overall the lowest 
counts were obtained on low $\mathrm{a}_{\mathrm{w}}$ media: on MY10-12 up to $2.5 \times 10 \mathrm{CFU} / 100 \mathrm{ml}$ and on DG-18 up to $3 \times 10^{5} \mathrm{CFU} / 100 \mathrm{ml}$. DRBC counts ranged from 0 to $2.3 \times 10^{2} \mathrm{CFU} / 100 \mathrm{ml}$. Significantly higher counts were obtained on low nutrient media: on $\mathrm{MM}$ up to $7 \times 10^{4} \mathrm{CFU} / 100 \mathrm{ml}$ and on SNA up to $3.6 \times 10^{5} \mathrm{CFU} / 100 \mathrm{ml}$.

The overall lowest counts were detected in fresh snow, with fungal counts, ranging from 0 (DRBC) to $2 \times 10$ $\mathrm{CFU} / 100 \mathrm{ml}$ (MM and DG-18). In contrast, samples from cryoconites holes had the highest fungal abundance with counts ranging from $5 \times 10^{4} \mathrm{CFU} / 100 \mathrm{ml}$ (DG-18 and $\mathrm{MM}$ ) to $3.6 \times 10^{5} \mathrm{CFU} / 100 \mathrm{ml}$ on SNA. Fungal abundance in dark ice spanned $2-8 \times 10 \mathrm{CFU} / 100 \mathrm{ml}$ on the two low $\mathrm{a}_{\mathrm{w}}$ media (MY10-12 and DG-18), but increased considerably on media with low nutrient concentrations (SNA, MM), where $\mathrm{CFU}$ ranged from 2 to $7 \times 10^{4} \mathrm{CFU} / 100 \mathrm{ml}$. Clear ice contained considerably lower counts than cryoconite and dark ice, ranging from 0 on DG-18 and MY10-12 to $6 \times 10$ $\mathrm{CFU} / 100 \mathrm{ml}$ on $\mathrm{MM}$ and SNA. CFU in supraglacial water were considerably higher relative to clear ice and snow and ranged from no isolates (DRBC and MY10-12) to $1 \times 10^{4} \mathrm{CFU} / 100 \mathrm{ml}$.

\section{Relative Quantification of Fungal Biomass With Ergosterol}

Quantification of ergosterol in samples collected during 2017 fieldwork is shown in Figure 2B.

Ergosterol levels were highest in cryoconite slur and dark ice compared to the other sampled habitats, with concentrations up to $162 \mathrm{ng} / \mathrm{ml}$ and $177 \mathrm{ng} / \mathrm{ml}$, respectively. Interestingly, biological replicates of samples with the highest levels showed high variability in ergosterol concentrations, with values ranging between 21.6 and $162 \mathrm{ng} / \mathrm{ml}$ in cryoconite slur, and 30 and $177 \mathrm{ng} / \mathrm{ml}$ in dark ice. However, even the smallest ergosterol quantities in the abovementioned samples were 10 times higher than any of the samples of fresh snow, clear ice and supraglacial water. Concentrations of ergosterol in supraglacial water and clear ice were similar, with values from 3.6 to $3.9 \mathrm{ng} / \mathrm{ml}$, and 2.4 to $3.6 \mathrm{ng} / \mathrm{ml}$, respectively. The lowest levels of ergosterol, from undetectable to $0.66 \mathrm{ng} / \mathrm{ml}$, were found in fresh snow.

\section{Cultivable Fungal Diversity}

A total of 260 fungal isolates were obtained from all five habitats sampled in 2017. Cultivation identified dark ice as the habitat with the most diverse fungal community, with many of these species plant pathogens or endophytes. Commonly isolated yeasts associated with dark ice were the ascomycetous black yeast Oleoguttula mirabilis and two basidiomycetous yeasts, Glaciozyma antarctica-like and Rhodotorula "svalbardensis". Other yeasts that were isolated sporadically were Vishniacozyma victoriae, Dothiora sp., Mrakia sp., Phenoliferia glacialis, Sporobolomyces ruberrimus, Tilletiopsis washingtonensis and Basidiomycota sp. 2, 4, 6 (Uetake et al., 2012) (total CFUs in $100 \mu \mathrm{l}$ of dark ice belonging to yeasts ranged from 2 to 90). Filamentous fungi commonly isolated from dark ice were Cladosporium sp., and Claussenomyces sp. Less frequently isolated fungi were Acrodontium luzulae, Epicoccum sp., Aspergillus sp., Athelia sp., Bjerkandera adusta, Cadophora sp., Comoclathris lini, Comoclathris sp., unidentified Helotiales, Microdochium nivale, Penicillium bialowiezense, and Venturia sp. (total CFUs in $100 \mu \mathrm{l}$ of dark ice belonging to filamentous fungi ranged from 1 to 13). In comparison to dark ice, a much lower recovery of cultivable species was obtained from clear ice. However, Oleoguttula mirabilis, Glaciozyma antarctica-like and Rhodotorula "svalbardensis" remained the most common taxa, with Baeospora myosura, Basidiomycota sp. 2 (Uetake et al., 2012), Coleophoma sp., and Penicillium solitum isolated sporadically. Species characteristic of supraglacial water included basidiomycetous yeast such as Glaciozyma antarctica-like, one of the dominant yeasts both in dirty ice and clear ice, and additionally Ph. glacialis, Ph. sp., Basidiomycota sp. 2 (Uetake et al., 2012), Glaciozyma watsonii, and Mrakia sp. Filamentous fungi such as Cladosporium sp. and unidentified Helotiales were occasionally present.

Despite the low fungal abundance, fresh snow had the second highest fungal diversity - and no dominant species - assessed both by cultivation and molecular methods (see below). Filamentous

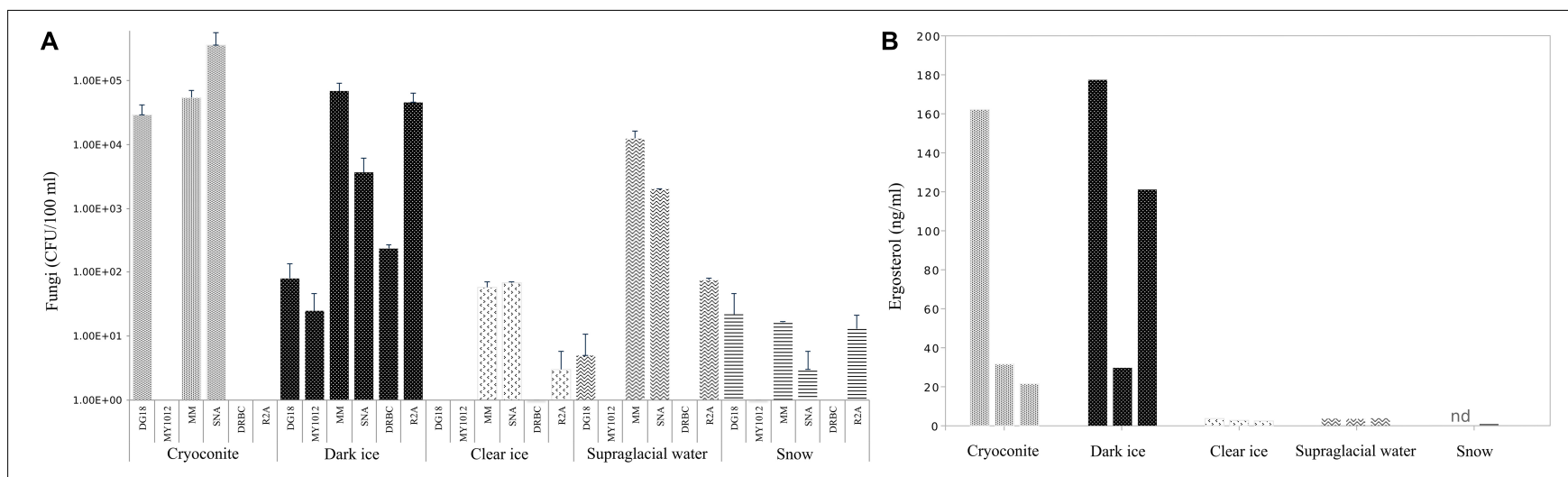

FIGURE 2 | Fungal abundances (A) in CFU/100 ml and ergosterol concentration (B) in ng/ml in cryoconite, dark ice, clear ice, supraglacial water and snow. Abundance data were log-transformed and errors bar denoted standard deviation. 
fungi were represented by Preussia sp., Neocucurbitaria sp., Cladosporium sp., Comoclathris sp., Sydowia polyspora, Hyalodendriella betulae, Coniochaeta rosae, Penicillium chrysogenum, P. crustosum, P. fusisporum, Penicillium sp., Thelebolus globosus, Venturia sp., and unidentified Ascomycota. Yeast species included Aureobasidium pullulans, Vishniacozyma carnescens, unidentified Dothideomycetes, Vishniacozyma victoriae, Cystofilobasidium capitatum, Dothiora sp., Mrakia sp., and Tilletiopsis washingtonensis. The principal component analyses (PCA) of the cultivable fungal diversity showed dark ice and snow as the habitats with the most diverse fungal communities compared to cryoconite, supraglacial water and clear ice (Supplementary Material). Furthermore, SIMPER analyses identified dark ice and snow as the habitats that contributed the most to the overall dissimilarity (Supplementary Material), with some species such as Acrodontium luzulae, Epicoccum sp., Aspergillus sp., Athelia sp., Bjerkandera adusta, Cadophora sp., Claussenomyces sp., Microdochium nivale, Penicillium bialowiezense, Sporobolomyces ruberrimus present just in dark ice samples.

Cryoconite holes differed from all other communities by a high presence of Articulospora sp., present to a lesser extent also in plated ice algae. As in clear and dark ice, Rhodotorula "svalbardensis" was the dominant species also in cryoconites. Other sporadic fungal species were Cladosporium sp., Vishniacozyma victoriae, Dothiora europaea, Mrakia sp., Glaciozyma antarctica-like, and Preussia sp.

\section{Fungal Diversity (Amplicon Sequencing)}

In total 4,357,151 single-end reads were obtained from 15 samples, corresponding to 697 different operational taxonomic units (OTUs). The number of reads per sample ranged from 109,100 (Cry17-1) to 434,630 (S-wtr17-1), with the exception of sample $S$-wtr16, where the number of reads was much lower $(39,737)$, therefore this sample was excluded from analyses of alpha and beta diversity. Sequence data generated and analyzed during the current study are available in GenBank under the BioProject with the accession code PRJNA507743.

Shannon indices (Supplementary Material) varied over a broad range from $\mathrm{H}^{\prime}=2.28$ (D-ice17-1) to $\mathrm{H}^{\prime}=4.7$ (Snow172 ), revealing differences in diversity between habitats. To test for differences between sample types, PERMANOVA multivariate diversity analyses were performed. Significant differences were found between all five types of samples (i.e., dark ice, clear ice, snow, cryoconite hole, supraglacial water, pseudo- $\mathrm{F}=2.78$; $p=0.001$; the number of permutations $=999)$. However, no statistically significant differences were found in the pairwise PERMANOVA comparisons of sample types, possibly due to the small numbers of samples of each sample type.

Clear ice, dark ice and supraglacial water samples from both years (2016 and 2017) were dominated by Microbotryomycetes (Basidiomycota) (Figure 3A), with relative frequencies above $68 \%$ (frequency of this group was $68.2-94.7 \%$ in clear ice, $93.3-95.3 \%$ in dark ice, and $76.8-96.8 \%$ in supraglacial water). Analyses at lower taxonomic levels revealed that a large part of the sequences within the Microbotryomycetes class was unassigned, while $17.2-69.4 \%$ were identified to the order Leucosporidiales. Cryoconite samples were still dominated by Microbotryomycetes class (36.8-40.7\%), followed by Chytridiomycota phylum (22.8-26.3\%). The phylum Chytridiomycota was also present in all the other samples, except for snow, with lower frequencies (0.01-2.1\% in clear ice, $2.2-3.4 \%$ in dark ice, and $0.9-18.6 \%$ in supraglacial water). Snow samples were dominated by 45.2-75.6\% Dothideomycetes (Ascomycota) and by 45.7-5.5\% Agaricomycetes (Basidiomycota). Although black yeast genus Aureobasidium (Dothideales) represented $0.7-3 \%$ of the Dothideomycetes, the majority of this class (40.5-66.7\%) belonged to the Pleosporales, with the two most abundant families being Pleosporaceae (16.2-32.6\%) and Sporormiaceae $(14.8-23.7 \%)$ and the most abundant genus Comoclathris (9.4-31.4\%). Snow samples and clear ice 2017 samples were characterized by the presence of Rozellomycota phylum (8.6-5.8\% and 8-10.6\%, respectively). Dark ice from 2016 and 2017, clear ice from 2017 and snow contained Oleoguttula mirabilis sequences with a relative abundance $<1 \%$. The class Malasseziomycetes was present in clear ice, supraglacial water and cryoconite samples with a frequency $<1 \%$.

The PCA of ordination patterns revealed four separate sample clusters based on Bray-Curtis dissimilarity index (Figure 4A). The three axes of PCoA accounted for $84.5 \%$ of the variation. Dark ice samples clustered together with clear ice samples, while cryoconite, supraglacial water, and snow samples formed separate clusters, reflecting the distinct microbial communities of these samples types.

\section{Quantification of Cultivable Bacteria (R2A Medium)}

Abundances of bacteria on R2A medium are summarized in Figure 5. Cryoconite, dark ice and supraglacial water were the samples with the highest bacterial counts, from 5.0, 1.0, $3.0 \times 10^{5}$ CFU/100 ml, respectively. Clear ice followed with $1.3 \times 10^{2}$ $\mathrm{CFU} / 100 \mathrm{ml}$, while fresh snow had the lowest bacterial counts $2 \mathrm{CFU} / 100 \mathrm{ml}$.

\section{Diversity of Cultivable Bacteria}

Forty-six bacterial isolates were obtained from all five environments sampled in 2017. Cryoconites had the most diverse bacterial community. The most isolated species was Pseudomonas sp., followed by Rugamonas rubra, Janthinobacterium sp. and Undibacterium sp. Amongst sporadically isolated species were unidentified Oxalobacteraceae, and Sphingomonas sp.

In dark ice isolates belonged to Bacillus sp., Curtobacterium sp., Frigoribacterium sp., uncultured Oxalobacteraceae similar to isolates from Arctic sea ice (Brinkmeyer et al., 2003), Rugamonas rubra, and Sphingomonas glacialis. In clear ice the majority of isolates were Cryobacterium sp., but also species such as Rugamonas rubra, Bacillus sp., Frigoribacterium sp., and an unidentified species belonging to Oxalobacteraceae family were found.

Supraglacial water was dominated by so far uncultured species belonging to Oxalobacteraceae family, Janthinobacterium sp., and Massilia sp. Mesorhizobium sp. and Sphingomonas sp. 

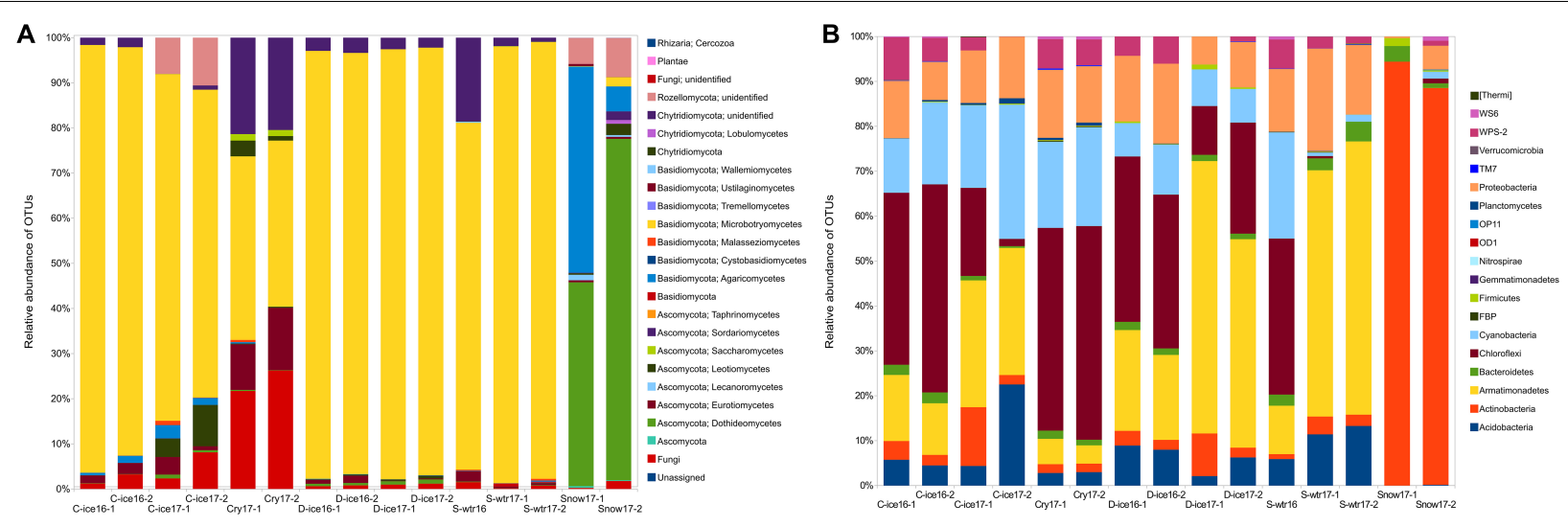

FIGURE 3 | Percent of fungal (A) and bacterial (B) operational taxonomic units (OTUs) aligned and assigned to known fungal classes/bacterial phyla based on PCR amplifications of ITS2/16S gene sequences for all the sample types.

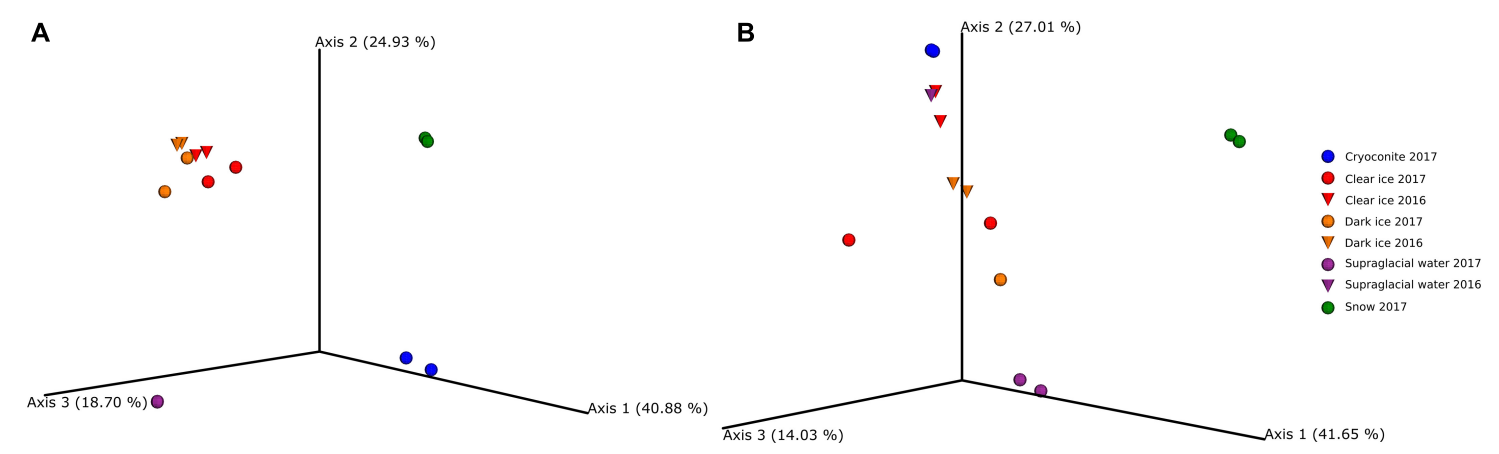

FIGURE 4 | Principal coordinate analysis (PCoA) ordination patterns based on Bray-Curtis dissimilarity index of fungi (A) and bacteria (B).

were sporadic. In snow samples the only isolate belonged to Curtobacterium sp.

\section{Diversity of Bacteria (Amplicon Sequencing)}

After subtraction of chloroplast sequences, the dataset was composed of 605,531 assembled sequences (for 15 samples in total), corresponding to 883 different features OTUs. Number of reads per sample ranged from 2,067 (Dice17-1) to 108,084 (S-wtr17-1). Sequence data generated and analyzed during the current study are available in GenBank under the BioProject with the accession code PRJNA517071.

Shannon indices (Supplementary Material) for bacteria varied over a broad range from $\mathrm{H}^{\prime}=2.73$ (Snow17-1) to $\mathrm{H}^{\prime}=5.74$ (S-wtr16). Samples with lower bacterial diversity indices were C-ice17-2, D-ice17-1 and 2, Snow17-1 and 2. PERMANOVA multivariate diversity showed differences between all five sample types (i.e., dark ice, clear ice, snow, cryoconite, supraglacial water, pseudo- $\mathrm{F}=2.38 ; p=0.001$, and the number of permutations $=999$ ). Pairwise PERMANOVA identified statistically significant differences between dark ice and supraglacial water $(p<0.005)$, but no other significant differences were found (as in the case of fungi, possibly due to a small number of samples per sample type).

The common bacterial phyla across all 15 samples were Actinobacteria, Bacteroidetes, Proteobacteria, and Cyanobacteria, with broad ranges of relative abundances (1.1-94.4\%, 0.4-4.4\%, 0.3-22.8\%, 0.8-29.9\%, respectively) (Figure 3B). However, many taxa were environment-specific. For instance, snow was dominated by the genus Micrococcus (Actinobacteria; 86.5-94.4\%), which was represented by few sequences in other samples $(<1 \%)$, while the genus Hymenobacter (Bacteroidetes) and the phylum Acidobacteria were present in all other samples except snow. Phylum Armatimonadetes was present in ice and supraglacial water from 2017 in high abundance (10.8-60.8\%). Its presence was lower in cryoconites (4.17-5.6\%), while it was absent from snow. Cryoconite samples were characterized by the classes Chloroflexi (mainly class Ktedonobacteria) and WPS-2. Genus Polaromonas was found in ice from 2016 and supraglacial water from both sampling years.

The PCA of ordination patterns revealed five separate sample clusters based on Bray-Curtis dissimilarity index (Figure 4B). The three axes of the PCoA accounted for $82.7 \%$ of the variation. Samples of clear ice, and one replicate of dark ice from 2017 clustered together. The second cluster was composed 


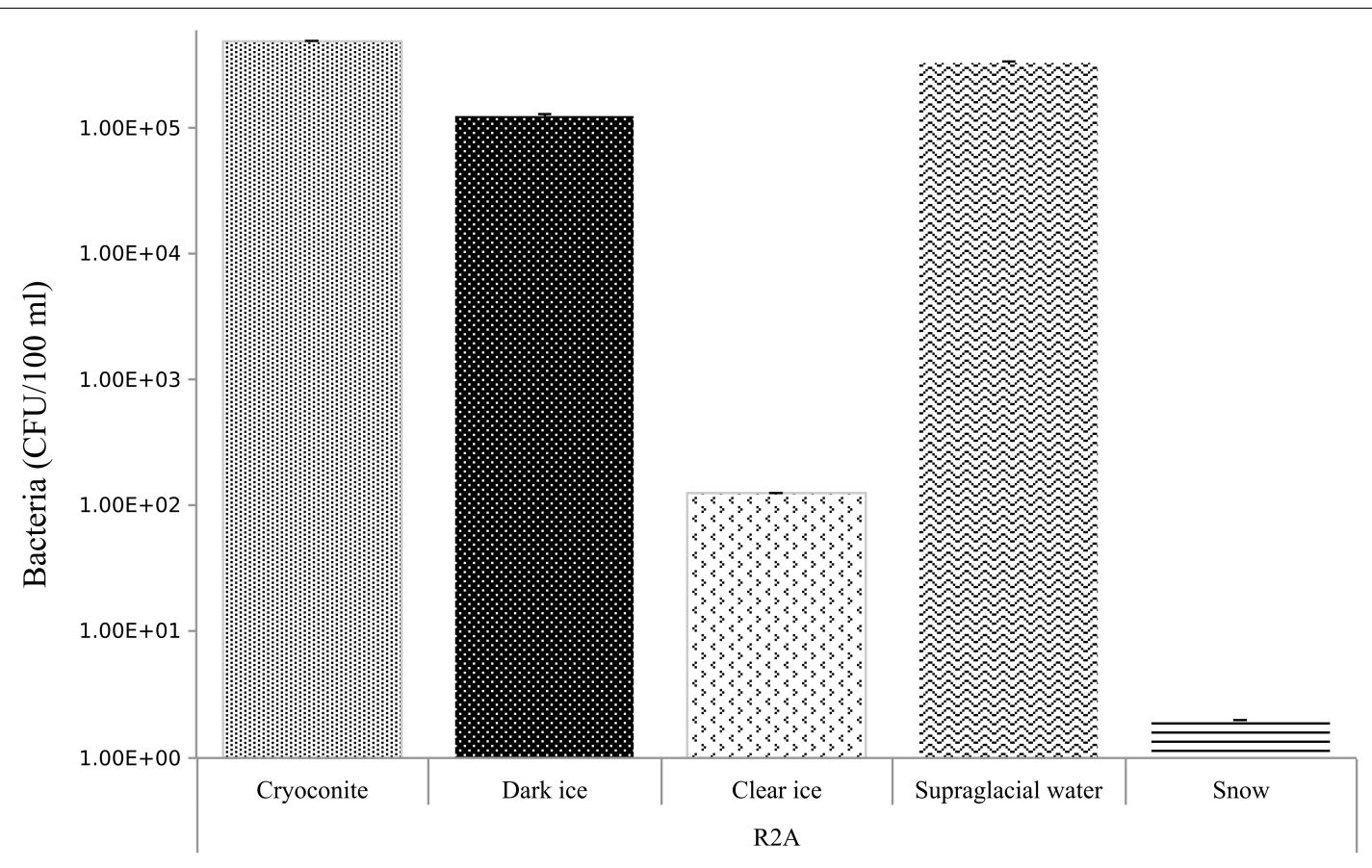

FIGURE 5 | Bacterial abundances in CFU/100 ml in cryoconite, dark ice, clear ice, supraglacial water and snow. Errors bar denoted standard deviation. Abundance data were log-transformed.

of supraglacial water and dark ice samples, both from 2016, and cryoconite. As in the case of fungal diversity, snow and supraglacial water 2017 were clearly separated from the rest, reflecting a distinct microbial diversity.

\section{DISCUSSION}

This is the first study to characterize the fungal diversity and abundance across different habitats of the surface of the GrIS using both cultivation and sequencing approaches. Particular emphasis was given to algal dominated ice in comparison to other habitats due to its impact on surface albedo and potential to exacerbate surface melt. In this study, we use the information about fungal diversity in the different supraglacial habitats to speculate potential roles of supraglacial fungal community in association with ice algae, such as a saprotrophic role in degradation of the algal biomass, but also possibly pathogenic or symbiotic relationship, either as endophytes relieving stress conditions or akin to those of lichens helping the ice algae in stabilizing themselves on the ice. Interactions between fungi and ice algae may thus influence GrIS ice algal bloom dynamics, and consequently hold potential to indirectly impact ice surface albedo and melt.

\section{Ice With Blooming Algae Supports a Higher Fungal and Bacterial Abundance}

Fungal abundance was estimated across five different surface habitats of the GrIS via cultivation and ergosterol measurements.
The relative amounts of ergosterol confirmed the fungal abundance determined by cultivation in cryoconite and dark ice. $\mathrm{MM}$, due to its low nutrient concentration, limits the growth of highly sporulating fungi and thus reduces the overestimation of their number. This may be the explanation of why in our study, MM is the medium that better reflected the real abundance of fungi and that correlated with the ergosterol quantification with a correlation coefficient of $0.726(p=0.011)$. Ergosterol on Canadian soil samples measured with HPLC procedure by Montgomery et al. (2000) showed quantifications ranging from 130 to $1,210 \mathrm{ng} / \mathrm{ml}$. Lowest concentration reported in soil is comparable with concentrations measured for cryoconite and dark ice habitats in this study. Although ergosterol is commonly used as biomarker in various types of environmental samples to estimate the abundance of living fungal biomass (Gessner, 2005), this is the first use of ergosterol as a biomarker in glacial ice of Arctic or Antarctic environments. Since ergosterol content can vary considerably between fungal species, growth phase and culturing conditions, converting ergosterol measurements to biomass can be inaccurate. Also, early lineages fungi detected with amplicon sequencing and observed in abundance in some habitats, such as Chytridiomycota, do not synthetize ergosterol (Newell, 2001). On the other hand, the presence of nonfungal ergosterol producers, such as green algae belonging to the genus Chlamydomonas (Brumfield et al., 2017) in the studied habitats is possible. Conversion factors can lead to both an under- or over-estimation of the fungal biomass (Gessner and Newell, 2002); therefore conversion to biomass was not attempted in this study, with data interpreted in a relative manner between habitats. 
In contrast to fungi, bacterial abundance in different cold environments (Foreman et al., 2007; Anesio and LaybournParry, 2012) and in Greenland has been determined previously (Stibal et al., 2015). However, in these studies the authors used a direct counting method by epifluorescence microscopy, thereby including non-viable cells. Bacterial concentrations reported from the Arctic, European Alps, and Tateyama Mountains (Japan) range from $1.1 \times 10^{4}$ to $2.3 \times 10^{5}$ cells $/ \mathrm{ml}$ (Anesio and Laybourn-Parry, 2012), and specifically from the GrIS, $10^{3}-10^{6}$ cells per $\mathrm{ml}$ of melted ice, and $10^{3}-10^{4}$ cells per $\mathrm{ml}$ of supraglacial snow (Stibal et al., 2015). Our results ranged from $2 \times 1$ to $5 \times 10^{5}$ of CFU per $100 \mathrm{ml}$ (Figure 5). Samples with the highest abundance were cryoconite, dark ice, and supraglacial water.

\section{Air-Deposited Mycobiota Undergoes a Selection Process Driven by the Specific Conditions of Various Supraglacial Habitats}

In contrast to the general trends in fungal community distribution in temperate zones, which shows prevalence of filamentous ascomycetous fungi, terrestrial polar and subpolar habitats are dominated by basidiomycetous yeasts (Timling et al., 2014) and ascomycetous black yeasts (Onofri et al., 1999). Comparison studies of fungal communities in cold water-icebased environments in the Arctic are rare and mostly limited to selected habitats on Svalbard, such as cryoconite (Singh and Singh, 2012; Edwards et al., 2013) and subglacial ice (Sonjak et al., 2006; Butinar et al., 2007). We reveal here the presence of an abundant and diverse fungal population in GrIS surface ice and melt water samples, which is composed of members of Ascomycota, Basidiomycota, Chytridiomycota, and Rozellomycota phyla. Many of the fungal species identified in this study have also been found by Rämä et al. (2016) in North Atlantic driftwood indicating a surprising ability of certain fungal species to inhabit environments as different as glacial and marine. Our cultivation approach served to indicate differences in species composition between habitats, although substantial overlap of the most frequent species between some habitats was apparent, as highlighted by the PCoA of the fungal cultivable diversity (Supplementary Material). This overlap was more pronounced in our amplicon sequencing data that revealed a high similarity and low diversity in fungal taxa across all habitats except snow, and a high abundance of sequences assigned to the class Microbotryomycetes (Basidiomycota), as previously observed for Icelandic (Lutz et al., 2015) and Patagonian (Duo Saito et al., 2018) glaciers. We found high proportion of Chytridiomycota sequences in cryoconite samples and the presence of this phylum in all glacial samples, except snow. This is similar to other observations from Antarctic ice-covered lakes (Rojas-Jimenez et al., 2017), Svalbard cryoconites (Edwards et al., 2013) and Patagonian ice and snow (Duo Saito et al., 2018).

The majority of species from snow, determined by both cultivation and amplicon sequencing, belonged to Pleosporales, the largest order in the Dothideomycetes, comprising a quarter of all dothideomycetous species (Kirk et al., 2008). Within the Dothideomycetes, Aureobasidium and Cladosporium (represented in the samples between 0.3 and 1.2\%) are two genera known for their stress tolerance, and are consistently isolated from extreme environments (Gunde-Cimerman et al., 2003; Turchetti et al., 2008; Zalar et al., 2012). Many isolates from snow belonged to various Penicillium spp., but $P$. bialowiezense was the only penicillium that was also recovered from dark ice. Snow and dark ice fungal communities were most dissimilar, using both cultivation and NGS techniques. The significant variation in fungal taxa between ice and snow samples suggests that the communities in ice and supraglacial water are far from being simple collections of aeolian deposits. This indicates that after deposition they have undergone a process of selection and enrichment in accordance to the specific conditions within the habitat in question.

The dominant fungi both cultivated and sequenced from dark ice were yeasts Oleoguttula mirabilis, Rhodotorula "svalbardensis" and Glaciozyma antarctica-like, (sporadically also isolated from clear ice as well). Oleoguttula mirabilis, reported for the first time in the Arctic, is a new species from a recently described genus of black meristematic fungi (Egidi et al., 2014), previously known only from the Antarctic rocks as members of the cryptoendolithic communities (Selbmann et al., 2005, 2008; Egidi et al., 2014). Considering its rock associated life style, in GrIS O. mirabilis could be associated with the mineral dust present on the dark ice and reported to play an important role as nutrient source for the ice algae (Stibal et al., 2017) and acting as hot spots of algal growth (Stibal et al., 2017). The high presence of O. mirabilis in dark ice samples could thus be explained by dust particles fallen with the snow and embedded within the EPS of ice algal aggregations. Rhodotorula svalbardensis is a novel psychrophilic yeast previously isolated only from glacier cryoconite holes of Svalbard (Singh et al., 2014). However, its existing description is not valid due to the undetermined type strain and missing name in either Mycobank or Index Fungorum. This is the first report on its occurrence on ice and cryoconite samples in the GrIS. Glaciozyma antarctica, formerly Leucosporidium antarcticum (Turchetti et al., 2011), is considered a true psychrophile, typical of cold environments, described previously from Alpine and/or Apennine glacier-associated sediments and/or Antarctic soil and sea water (Turchetti et al., 2011). It has been widely studied due to its high production of antifreeze proteins and cold-active enzymes of potential biotechnological importance (Turkiewicz et al., 2003; Ramli et al., 2012; Hashim et al., 2013). Besides these dominant species additionally many different yeasts were sporadically isolated with species belonging mainly to genera Mrakia and Phenoliferia identified in previous studies from glacial habitats, particularly glacier melt-water (Margesin and Fell, 2008; Branda et al., 2010; Pathan et al., 2010). The same melanised Cladosporium species as isolated from snow, representing a different fungal diversity, were also isolated from dark ice, suggesting deposition by air-borne spores.

Ascomycetous genera, such as Acrodontium, Epicoccum, Preussia, snow mold fungus Microdochium nivale (Hoshino et al., 2009), which contain species recognized as plant endophytes and plant pathogens, reported mainly from boreal, polar and alpine environments (Sati and Belwal, 2005; Sogonov et al., 2005; Bridge and Newsham, 2009), and basidiomycetous 
Bjerkandera have only been retrieved from dark ice samples. Brown et al. (2015) suggested that snow algae might act as an environmental filter that structures the snow-borne fungal community. Ice algae may perform a similar role on dark ice of GrIS. In the dark ice GrIS surface, ice algal abundances can reach up to $10^{4}$ cells $/ \mathrm{ml}$ and their ability to accumulate organic carbon on the ice surface was previously demonstrated by net ecosystem production measurements (Yallop et al., 2012; Williamson et al., 2018). High primary production of the ice algae represents an important source of organic matter and nutrients (Brown et al., 2015) that may support dense fungal and bacterial communities. Brown et al. (2015) already reported a co-occurrence of snow algae with the snow-borne fungal community. Furthermore, ice algae are amongst the closest living relatives to land plants. Recent phylogenetic analyses of hundreds of proteins concluded that the Zygnematophyceae constitute the streptophyte algal group that branches closest to embryophytes (de Vries and Archibald, 2018). Ancestral streptophytes likely possessed exaptations that provided them with an advantage to terrestrial life. One of the several important adaptations required for a transition from aquatic to terrestrial habitats was the ability to form symbiotic relationships with fungal communities in order to access vital nutrient resources. Members of Helotiales found in this study are Ascomycetes related to rare mycorrhizal fungi, which are associated with the plant family Ericaceae growing in polar areas (Newsham et al., 2009; Tedersoo et al., 2009; Walker et al., 2011). Therefore, in addition to simply acting as decomposers, fungi could have positive or negative, not yet described, relationships with the ice algae. Cryoconite sampled with both amplicon sequencing and cultivation techniques highlighted a low fungal diversity. Sample plates from cultivation were dominated by Articulospora sp., a fresh water fungus belonging to the family Helotiales, that was also found when plating concentrated ice algae (data not shown). Its presence was observed in close association with clumps of dead and alive ice algae, kept together by algal EPS, suggesting a potential role in the degradation of the ice algae. Articulospora has been previously described in cryoconite holes in Svalbard (Singh and Singh, 2012; Edwards et al., 2013; Singh et al., 2016) and its role as an important carbon decomposer was hypothesized. This result was confirmed by amplicon sequencing (Cladochasiella divergens; 0.11-0.15\%) that furthermore showed the presence of the plant-associated black yeast genus Cladophialophora (9.2-12.6\%). Other species obtained by cultivation were mainly basidiomycetous yeasts, such as Mrakia sp., Rh. "svalbardensis", and Glaciozyma antarctica-like typical for polar habitats (see above).

Finally, we observed a substantial difference in cultivable fungal diversity between the sampling seasons of 2016 and 2017. The majority of isolates cultivated from 2016 sampling belonged to Penicillium bialowiezense-like (data not shown), dominating in all the environments, while in 2017 the isolates were much more diverse and belonged to 33 different genera. Two possible reasons for the observed differences could be the different snow conditions on the GrIS between 2016 (after the snow melting) and 2017 (before the snow melting), and the use of a wider selection of media in 2017. The results of amplicon sequencing, however, did not show such stark dissimilarity between the seasons, possibly pointing to insufficient sampling of the total fungal community with cultivation methods or their greater bias.

\section{Bacterial Communities}

Heterotrophic bacteria are common within the various supraglacial habitats where they play an important role in nutrient cycling of decaying organic matter and remineralization of the limited nutrients available. Bacterial populations of the GrIS supraglacial environments have been studied for years (Yallop et al., 2012; Cameron et al., 2015a,b; Musilova et al., 2015; Stibal et al., 2015; Williamson et al., 2018), facilitating a comparison of our 16S rRNA results with previous studies. However, none of these studies have targeted the bacterial community associated with the ice algae in dark ice on the SW margin of the GrIS.

In line with previous studies (Larose et al., 2010; Edwards et al., 2011; Cameron et al., 2012) Proteobacteria (mainly alpha-proteobacteria), Bacteroidetes and Actinobacteria were present in all our samples. This result was supported by amplicon sequencing and by cultivation. Dark ice 2017 was dominated in particular by the phylum Armatimonadetes (order FW68) that was present the same year to a lesser extent also in supraglacial water and clear ice. Classes of this phylum have been recovered from a broad range of temperatures and environmental niches, such as terrestrial and aquatic habitats, human skin, anaerobic bioreactors and waste water treatment plans, geothermal soils and springs (Lee et al., 2014). Armatimonadetes strains are commonly detected in areas dominated by photosynthetic bacteria or eukaryotes and they are most probably involved in the degradation of photosynthetic plant and microbial biomass and polysaccharide-based substances (Burns et al., 2004; Ley et al., 2006; Isenbarger et al., 2008; Pope and Patel, 2008; Shao et al., 2011; Lee et al., 2014). Class Ktedonobacteria (Chloroflexi) was especially abundant in cryoconites, but also present in all other samples except snow. Ktedonobacteria are Grampositive and aerobic, with a complex morphology, forming branched mycelia with spores similar to mycelia-forming actinomycetes. They are prominent in extreme environments such as volcanic, Antarctic, and cave ecosystems (GomezAlvarez et al., 2007; Barton et al., 2014; Kim et al., 2015; Tebo et al., 2015). Snow samples were substantially different from all other sampled habitats and, as reported previously (Amato et al., 2007; Cheng and Foght, 2007), were dominated by Actinobacteria, usually identified as key components in cryoconite (Gokul et al., 2016).

\section{CONCLUSION}

This is the first report of fungal communities in GrIS waterbased ecosystems and one of the few culture independent studies of microbial diversity in ice. In our amplicon sequencing 
based study of the microbial variety of GrIS supraglacial habitats, we described more diverse bacterial communities than fungal communities. Combining different approaches was thus beneficial in these extreme environments with low biodiversity. Dark ice fungal communities were characterized by plant pathogenic fungi and endophytes and a much higher fungal and bacterial abundance than in other supraglacial habitats on the GrIS, underlining its distinctiveness and suggesting that ice algal clumps probably influence the associated microbial diversity and abundance. In particular, fungal roles in the prospering and degradation of ice algal blooms should be investigated further. Since the darkening of ice (in part due to algal blooms) has the potential to significantly increase GrIS surface melt, interactions between all microbial communities in this specific habitat should be studied in more detail.

\section{DATA AVAILABILITY}

The datasets generated for this study can be found in GenBank, MK460310-MK460422, MK454775-MK454866, MK453054MK453127, PRJNA507743, and PRJNA517071.

\section{AUTHOR CONTRIBUTIONS}

LP collected the samples with the support of AA and CW. LP performed the wetlab analyses. CG performed the bioinformatic analyses of NGS data. LP and CG analyzed the data. LP, NG-C, and CG interpreted the data with contributions from AA and CW. LP drafted the manuscript.

\section{REFERENCES}

Abarenkov, K., Henrik Nilsson, R., Larsson, K. H., Alexander, I. J., Eberhardt, U., Erland, S., et al. (2010). The UNITE database for molecular identification of fungi-recent updates and future perspectives. New Phytol. 186, 281-285. doi: $10.1111 /$ j.1469-8137.2009.03160.x

Abdalati, W., and Steffen, K. (1995). Passive microwave-derived snow melt regions on the Greenland ice sheet. Geophys. Res. Lett. 22, 787-790. doi: 10.1029/ 95GL00433

Alstrup, V., Hansen, E. S., and Daniels, F. J. (2000). Lichenized, lichenicolous and other fungi from North and North-East Greenland. Folia Cryptogam. Est. 37, $1-20$.

Altschul, S. F., Gish, W., Miller, W., Myers, E. W., and Lipman, D. J. (1990). Basic local alignment search tool. J. Mol. Biol. 215, 403-410. doi: 10.1016/S00222836(05)80360-2

Amato, P., Hennebelle, R., Magand, O., Sancelme, M., Delort, A. M., Barbante, C., et al. (2007). Bacterial characterization of the snow cover at Spitzberg, Svalbard. FEMS Microbiol. Ecol. 59, 255-264. doi: 10.1111/j.1574-6941.2006. 00198.x

Anesio, A. M., and Laybourn-Parry, J. (2012). Glaciers and ice sheets as a biome. Trends Ecol. Evol. 27, 219-225. doi: 10.1016/j.tree.2011.09.012

Barton, H. A., Giarrizzo, J. G., Suarez, P., Robertson, C. E., Broering, M. J., Banks, E. D., et al. (2014). Microbial diversity in a Venezuelan orthoquartzite cave is dominated by the Chloroflexi (Class Ktedonobacterales) and Thaumarchaeota Group I. 1c. Front. Microbiol. 5:615. doi: 10.3389/fmicb.2014.00615

Boekhout, T., and Kurtzman, C. P. (1996). "Principles and methods used in yeast classification, and an overview of currently accepted yeast genera," in Nonconventional Yeasts in Biotechnology, ed. K. Wolf (Berlin: Springer), 1-81. doi: 10.1007/978-3-642-79856-6_1
All authors contributed to design of the experiments, revised the manuscript draft, and approved the final version of the manuscript.

\section{FUNDING}

This project has received funding from the European Union's Horizon 2020 Research and Innovation Programme under the Marie Skłodowska-Curie grant agreement no. 675546.

\section{ACKNOWLEDGMENTS}

We sincerely thank Matevž Likar for his help with ergosterol quantification analyses and Boerge Diderichesen for carefully reading and commenting the manuscript. We further acknowledge support from the United Kingdom Natural Environment Research Council Consortium Grant 'Black and Bloom' (NE/M021025/1). We acknowledge the financial support from the Slovenian Research Agency to the Infrastructural Centre Mycosmo (MRIC UL) and to the programs P1-0170 and P1-0207.

\section{SUPPLEMENTARY MATERIAL}

The Supplementary Material for this article can be found online at: https://www.frontiersin.org/articles/10.3389/fmicb. 2019.00557/full\#supplementary-material

Branda, E., Turchetti, B., Diolaiuti, G., Pecci, M., Smiraglia, C., and Buzzini, P. (2010). Yeast and yeast-like diversity in the southernmost glacier of Europe (Calderone Glacier, Apennines, Italy). FEMS Microbiol. Ecol. 72, 354-369. doi: 10.1111/j.1574-6941.2010.00864.x

Bridge, P. D., and Newsham, K. K. (2009). Soil fungal community composition at Mars Oasis, a southern maritime Antarctic site, assessed by PCR amplification and cloning. Fungal Ecol. 2, 66-74. doi: 10.1016/j.funeco.2008.10.008

Brinkmeyer, R., Knittel, K., Jürgens, J., Weyland, H., Amann, R., and Helmke, E. (2003). Diversity and structure of bacterial communities in Arctic versus Antarctic pack ice. Appl. Environ. Microbiol. 69, 6610-6619. doi: 10.1128/AEM. 69.11.6610-6619.2003

Brown, S. P., Olson, B. J., and Jumpponen, A. (2015). Fungi and algae co-occur in snow: an issue of shared habitat or algal facilitation of heterotrophs? Arct. Antarct. Alp. Res. 47, 729-749. doi: 10.1657/AAAR0014-071

Brumfield, K. M., Laborde, S. M., and Moroney, J. V. (2017). A model for the ergosterol biosynthetic pathway in Chlamydomonas reinhardtii. Eur. J. Phycol. 52, 64-74. doi: 10.1080/09670262.2016.1225318

Burns, B. P., Goh, F., Allen, M., and Neilan, B. A. (2004). Microbial diversity of extant stromatolites in the hypersaline marine environment of Shark Bay, Australia. Environ. Microbiol. 6, 1096-1101. doi: 10.1111/j.1462-2920.2004. 00651.x

Butinar, L., Spencer-Martins, I., and Gunde-Cimerman, N. (2007). Yeasts in high Arctic glaciers: the discovery of a new habitat for eukaryotic microorganisms. Antonie Van Leeuwenhoek 91, 277-289. doi: 10.1007/s10482-006-9117-3

Callahan, B. J., McMurdie, P. J., Rosen, M. J., Han, A. W., Johnson, A. J. A., and Holmes, S. P. (2016). DADA2: high-resolution sample inference from Illumina amplicon data. Nat. Methods 13, 581-583. doi: 10.1038/nmeth.3869

Cameron, K. A., Hagedorn, B., Dieser, M., Christner, B. C., Choquette, K., Sletten, R., et al. (2015a). Diversity and potential sources of microbiota 
associated with snow on western portions of the Greenland Ice Sheet. Environ. Microbiol. 17, 594-609. doi: 10.1111/1462-2920.12446

Cameron, K. A., Hodson, A. J., and Osborn, A. M. (2012). Structure and diversity of bacterial, eukaryotic and archaeal communities in glacial cryoconite holes from the Arctic and the Antarctic. FEMS Microbiol Ecol. 82, 254-267. doi: 10.1111/j.1574-6941.2011.01277.x

Cameron, K. A., Stibal, M., Zarsky, J. D., Gözdereliler, E., Schostag, M., and Jacobsen, C. S. (2015b). Supraglacial bacterial community structures vary across the Greenland ice sheet. FEMS Microbiol. Ecol. 92:fiv164. doi: 10.1093/femsec/ fiv164

Caporaso, J. G., Kuczynski, J., Stombaugh, J., Bittinger, K., Bushman, F. D., Costello, E. K., et al. (2010). QIIME allows analysis of highthroughput community sequencing data. Nat. Methods 7, 335-336. doi: $10.1038 /$ nmeth.f.303

Carbone, I., and Kohn, L. M. (1999). A method for designing primer sets for speciation studies in filamentous ascomycetes. Mycologia 1, 553-556. doi: 10. $2307 / 3761358$

Cheng, S. M., and Foght, J. M. (2007). Cultivation-independent and-dependent characterization of bacteria resident beneath John Evans Glacier. FEMS Microbiol. Ecol. 59, 318-330. doi: 10.1111/j.1574-6941.2006.00267.x

Cook, J., Edwards, A., and Hubbard, A. (2015). Biocryomorphology: integrating microbial processes with ice surface hydrology, topography, and roughness. Front. Earth Sci. 3:78. doi: 10.3389/feart.2015.00078

Dahlberg, A., Bültmann, H., Cripps, C. L., Eyjólfsdóttir, G. G., Gulden, G., Kristinsson, H., et al. (2013). "Fungi," in Arctic Biodiversity Assessment. Status and Trends in Arctic Biodiversity, ed. H. Meltofte (Denmark: Narayana Press), 355-371.

de Vries, J., and Archibald, J. M. (2018). Plant evolution: landmarks on the path to terrestrial life. New Phytol. 217, 1428-1434. doi: 10.1111/nph.14975

de Vries, J., Stanton, A., Archibald, J. M., and Gould, S. B. (2016). Streptophyte terrestrialization in light of plastid evolution. Trends Plant Sci. 21, 467-476. doi: 10.1016/j.tplants.2016.01.021

de Vries, R. P., Burgers, K., van de Vondervoort, P. J., Frisvad, J. C., Samson, R. A., and Visser, J. (2004). A new black Aspergillus species, A. vadensis, is a promising host for homologous and heterologous protein production. Appl. Environ. Microbiol. 70, 3954-3959. doi: 10.1128/AEM.70.7.3954-3959.2004

Duo Saito, R. A., Connell, L., Rodriguez, R., Redman, R., Libkind, D., and de Garcia, V. (2018). Metabarcoding analysis of the fungal biodiversity associated with Castaño Overa Glacier-Mount Tronador, Patagonia, Argentina. Fungal Ecol. 36, 8-16. doi: 10.1016/j.funeco.2018.07.006

Edgar, R. C. (2004). MUSCLE: multiple sequence alignment with high accuracy and high throughput. Nucleic Acids Res. 32, 1792-1797. doi: 10.1093/nar/gkh340

Edwards, A., Anesio, A. M., Rassner, S. M., Sattler, B., Hubbard, B., Perkins, W. T., et al. (2011). Possible interactions between bacterial diversity, microbial activity and supraglacial hydrology of cryoconite holes in Svalbard. ISME J. 5, 150-160. doi: 10.1038/ismej.2010.100

Edwards, A., Douglas, B., Anesio, A. M., Rassner, S. M., Irvine-Fynn, T. D., Sattler, B., et al. (2013). A distinctive fungal community inhabiting cryoconite holes on glaciers in Svalbard. Fungal Ecol. 6, 168-176. doi: 10.1016/j.funeco. 2012.11.001

Egidi, E., De Hoog, G. S., Isola, D., Onofri, S., Quaedvlieg, W., de Vries, J., et al. (2014). Phylogeny and taxonomy of meristematic rock-inhabiting black fungi in the Dothideomycetes based on multi-locus phylogenies. Fungal Divers. 65, 127-165. doi: 10.1007/s13225-013-0277-y

Foreman, C. M., Sattler, B., Mikucki, J. A., Porazinska, D. L., and Priscu, J. C. (2007). Metabolic activity and diversity of cryoconites in the Taylor Valley, Antarctica. J. Geophys. Res. 112, 1-11. doi: 10.1029/2006JG000358

Gadd, G. M. (2007). Geomycology: biogeochemical transformations of rocks, minerals, metals and radionuclides by fungi, bioweathering and bioremediation. Mycol. Res. 111, 3-49. doi: 10.1016/j.mycres.2006.12.001

Gessner, M. O. (2005). "Ergosterol as a measure of fungal biomass," in Methods to Study Litter Decomposition: a Practical Guide, eds M. A. S. Graça, F. Bärlocher, and M. O. Gessner (Dordrecht: Springer), 189-195. doi: 10.1007/1-4020-34660_25

Gessner, M. O., and Newell, S. Y. (2002). "Biomass, growth rate, and production of filamentous fungi in plant litter," in Manual of Environmental Microbiology, ed. H. J. Christon (Washington, DC: ASM Press), 390-408.
Glass, N. L., and Donaldson, G. C. (1995). Development of primer sets designed for use with the PCR to amplify conserved genes from filamentous ascomycetes. Appl. Environ. Microbiol. 61, 1323-1330.

Gokul, J. K., Hodson, A. J., Saetnan, E. R., Irvine-Fynn, T. D., Westall, P. J., Detheridge, A. P., et al. (2016). Taxon interactions control the distributions of cryoconite bacteria colonizing a High Arctic ice cap. Mol. Ecol 25, 3752-3767. doi: $10.1111 / \mathrm{mec} .13715$

Gomez-Alvarez, V., King, G. M., and Nüsslein, K. (2007). Comparative bacterial diversity in recent Hawaiian volcanic deposits of different ages. FEMS Microbiol. Ecol. 60, 60-73. doi: 10.1111/j.1574-6941.2006.00253.x

Guindon, S., Dufayard, J. F., Lefort, V., Anisimova, M., Hordijk, W., and Gascuel, O. (2010). New algorithms and methods to estimate maximumlikelihood phylogenies: assessing the performance of PhyML 3.0. Syst. Biol. 59, 307-321. doi: 10.1093/sysbio/syq010

Gunde-Cimerman, N., Sonjak, S., Zalar, P., Frisvad, J. C., Diderichsen, B., and Plemenitaš, A. (2003). Extremophilic fungi in arctic ice: a relationship between adaptation to low temperature and water activity. Phys. Chem. Earth 28, 1273-1278. doi: 10.1016/j.pce.2003. 08.056

Hashim, N. H. F., Bharudin, I., Nguong, D. L. S., Higa, S., Bakar, F. D. A., Nathan, S., et al. (2013). Characterization of Afp1, an antifreeze protein from the psychrophilic yeast Glaciozyma antarctica PI12. Extremophiles 17, 63-73. doi: 10.1007/s00792-012-0494-4

Hocking, A. D., and Pitt, J. I. (1980). Dichloran-glycerol medium for enumeration of xerophilic fungi from low-moisture foods. Appl. Environ. Microbiol. 39, $488-492$.

Hoshino, T., Xiao, N., and Tkachenko, O. B. (2009). Cold adaptation in the phytopathogenic fungi causing snow molds. Mycoscience 50, 26-38. doi: 10. 1007/S10267-008-0452-2

Isenbarger, T. A., Finney, M., Ríos-Velázquez, C., Handelsman, J., and Ruvkun, G. (2008). Miniprimer PCR, a new lens for viewing the microbial world. Appl. Environ. Microbiol. 74, 840-849. doi: 10.1128/AEM.01933-07

Kim, M., Cho, A., Lim, H. S., Hong, S. G., Kim, J. H., Lee, J., et al. (2015). Highly heterogeneous soil bacterial communities around Terra Nova Bay of northern Victoria Land, Antarctica. PLoS One 10:e0119966. doi: 10.1371/journal.pone. 0119966

King, A. D., Hocking, A. D., and Pitt, J. I. (1979). Dichloran-rose bengal medium for enumeration and isolation of molds from foods. Appl. Environ. Microbiol. 37, 959-964.

Kirk, P. M., Cannon, P. F., Minter, D. W., and Stalpers, J. A. (2008). Dictionary of the Fungi. Wallingford: CABI.

Klindworth, A., Pruesse, E., Schweer, T., Peplies, J., Quast, C., Horn, M., et al. (2013). Evaluation of general 16S ribosomal RNA gene PCR primers for classical and next-generation sequencing-based diversity studies. Nucleic Acids Res. 41:e1. doi: 10.1093/nar/gks808

Kristinsson, H., Zhurbenko, M., and Steen Hansen, E. (2010). Pan-Arctic Checklist of Lichens and Lichenicolous Fungi. Available at: http://hdl.handle.net/11374/ 200

Lane, D. J. (1991). “16S/23S rRNA sequencing," in Nucleic Acid Techniques in Bacterial Systematics, eds E. Stackebrandt and M. Goodfellow (Chichester: John Wiley and Sons), 115-175.

Larose, C., Berger, S., Ferrari, C., Navarro, E., Dommergue, A., Schneider, D., et al. (2010). Microbial sequences retrieved from environmental samples from seasonal Arctic snow and meltwater from Svalbard, Norway. Extremophiles 14, 205-212. doi: 10.1007/s00792-009-0299-2

Lee, K. C., Dunfield, P. F., and Stott, M. B. (2014). “The phylum armatimonadetes," in The Prokaryotes, ed. E. Rosenberg (Berlin: Springer-Verlag), 447-458. doi: 10.1007/978-3-642-38954-2_388

Ley, R. E., Harris, J. K., Wilcox, J., Spear, J. R., Miller, S. R., Bebout, B. M., et al. (2006). Unexpected diversity and complexity of the Guerrero Negro hypersaline microbial mat. Appl. Environ. Microbiol. 72, 3685-3695. doi: 10.1128/AEM.72. 5.3685-3695.2006

Lutz, S., Anesio, A. M., Edwards, A., and Benning, L. G. (2015). Microbial diversity on Icelandic glaciers and ice caps. Front. Microbiol. 6:307. doi: 10.3389/fmicb. 2015.00307

Margesin, R., and Fell, J. W. (2008). Mrakiella cryoconiti gen. nov., sp. nov., a psychrophilic, anamorphic, basidiomycetous yeast from alpine and arctic 
habitats. Int. J. Syst. Evol. Microbiol. 58, 2977-2982. doi: 10.1099/ijs.0.2008/ 000836-0

McDonald, D., Price, M. N., Goodrich, J., Nawrocki, E. P., DeSantis, T. Z., Probst, A., et al. (2012). An improved Greengenes taxonomy with explicit ranks for ecological and evolutionary analyses of bacteria and archaea. ISME J. 6, 610-618. doi: 10.1038/ismej.2011.139

Meltofte, H., Barry, T., Berteaux, D., Bültmann, H., Christiansen, J. S., Cook, J. A., et al. (2013). Arctic Biodiversity Assesment. Synthesis. Conservation of Arctic Flora and Fauna (CAFF). Denmark: Narayana Press.

Montgomery, H. J., Monreal, C. M., Young, J. C., and Seifert, K. A. (2000). Determinination of soil fungal biomass from soil ergosterol analyses. Soil Biol. Biochem. 32, 1207-1217. doi: 10.1016/S0038-0717(00)00037-7

Musilova, M., Tranter, M., Bennett, S. A., Wadham, J., and Anesio, A. M. (2015). Stable microbial community composition on the Greenland Ice Sheet. Front. Microbiol. 6:193. doi: 10.3389/fmicb.2015.00193

Musilova, M., Tranter, M., Wadham, J., Telling, J., Tedstone, A., and Anesio, A. M. (2017). Microbially driven export of labile organic carbon from the Greenland Ice Sheet. Nat. Geosci. 10, 360-365. doi: 10.1038/ngeo2920

Newell, S. Y. (2001). Fungal biomass and productivity. Methods Microbiol. 30, 357-372. doi: 10.1016/S0580-9517(01)30053-3

Newsham, K. K., Upson, R., and Read, D. J. (2009). Mycorrhizas and dark septate root endophytes in polar regions. Fungal Ecol. 2, 10-20. doi: 10.1016/j.funeco. 2008.10.005

Nirenberg, H. I. (1981). A simplified method for identifying Fusarium spp. occurring on wheat. Can. J. Bot. 59, 1599-1609. doi: 10.1139/b81-217

Nylund, J. E., and Wallander, H. (1992). "Ergosterol analysis as a means of quantifying mycorrhizal biomass," in Methods in Microbiology, eds J. R. Norris, D. J. Read, and A. K. Varma (London: Academic Press Limited), 77-88. doi: 10.1016/S0580-9517(08)70088-6

Onofri, S., Pagano, S., Zucconi, L., and Tosi, S. (1999). Friedmanniomyces endolithicus (Fungi, Hyphomycetes), anam-gen and sp nov, from continental Antarctica. Nova Hedwigia 68, 175-182.

Pathan, A. A., Bhadra, B., Begum, Z., and Shivaji, S. (2010). Diversity of yeasts from puddles in the vicinity of midre lovenbreen glacier, arctic and bioprospecting for enzymes and fatty acids. Curr. Microbiol. 60, 307-314. doi: 10.1007/s00284009-9543-3

Pitt, J. I., and Hocking, A. D. (ed.). (2009). "The ecology of fungal food spoilage," in Fungi and Food Spoilage, (Boston, MA: Springer), 3-9. doi: 10.1007/978-0387-92207-2_2

Pope, P. B., and Patel, B. K. (2008). Metagenomic analysis of a freshwater toxic cyanobacteria bloom. FEMS Microbiol. Ecol. 64, 9-27. doi: 10.1111/j.1574-6941. 2008.00448.x

R Core Team (2017). R: A Language and Environment for Statistical Computing, Vol. 55. Vienna: R Foundation for Statistical Computing, 275-286.

Rämä, T., Davey, M. L., Nordén, J., Halvorsen, R., Blaalid, R., Mathiassen, G. H., et al. (2016). Fungi sailing the Arctic Ocean: speciose communities in North Atlantic Driftwood as Revealed by high-throughput amplicon sequencing. Microb. Ecol. 72, 295-304. doi: 10.1007/s00248-0160778-9

Rämä, T., Hassett, B. T., and Bubnova, E. (2017). Arctic marine fungi: from filaments and flagella to operational taxonomic units and beyond. Bot. Mar. 60, 433-452. doi: 10.1515/bot-2016-0104

Ramli, A. N. M., Mahadi, N. M., Shamsir, M. S., Rabu, A., Joyce-Tan, K. H., Murad, A. M. A., et al. (2012). Structural prediction of a novel chitinase from the psychrophilic Glaciozyma antarctica PI12 and an analysis of its structural properties and function. J. Comput. Aided Mol. Des. 26, 947-961. doi: 10.1007/ s10822-012-9585-7

Reasoner, D. J., and Geldreichm, E. E. (1985). A new medium for the enumeration and subculture of bacteria from potable water. Appl. Environ. Microbiol. 49, 1-7.

Remias, D., Holzinger, A., and Lütz, C. (2009). Physiology, ultrastructure and habitat of the ice alga Mesotaenium berggrenii (Zygnemaphyceae, Chlorophyta) from glaciers in the European Alps. Phycologia 48, 302-312. doi: $10.2216 / 08-13.1$

Remias, D., Holzinger, A., Aigner, S., and Lütz, C. (2012a). Ecophysiology and ultrastructure of Ancylonema nordenskiöldii (Zygnematales, Streptophyta), causing brown ice on glaciers in Svalbard (high arctic). Polar Biol. 35, 899-908. doi: 10.1007/s00300-011-1135-6
Remias, D., Schwaiger, S., Aigner, S., Leya, T., Stuppner, H., and Lütz, C. (2012b). Characterization of an UV-and VIS-absorbing, purpurogallin-derived secondary pigment new to algae and highly abundant in Mesotaenium berggrenii (Zygnematophyceae, Chlorophyta), an extremophyte living on glaciers. FEMS Microbiol. Ecol. 79, 638-648. doi: 10.1111/j.1574-6941.2011. 01245.x

Rojas-Jimenez, K., Wurzbacher, C., Bourne, E. C., Chiuchiolo, A., Priscu, J. C., and Grossart, H. P. (2017). Early diverging lineages within Cryptomycota and Chytridiomycota dominate the fungal communities in ice-covered lakes of the McMurdo Dry Valleys, Antarctica. Sci. Rep. 7:15348. doi: 10.1038/s41598-01715598-w

Ryan, J. C., Hubbard, A., Stibal, M., Irvine-Fynn, T. D., Cook, J., Smith, L. C., et al. (2018). Dark zone of the Greenland Ice Sheet controlled by distributed biologically-active impurities. Nat. Commun. 9:1065. doi: 10.1038/s41467-01803353-2

Sati, S. C., and Belwal, M. (2005). Aquatic hyphomycetes as endophytes of riparian plant roots. Mycologia 97, 45-49. doi: 10.3852/mycologia.97.1.45

Selbmann, L., De Hoog, G. S., Mazzaglia, A., Friedmann, E. I., and Onofri, S. (2005). Fungi at the edge of life: cryptoendolithic black fungi from Antarctic desert. Stud. Mycol. 51, 1-32.

Selbmann, L., De Hoog, G. S., Zucconi, L., Isola, D., Ruisi, S., van den Ende, A. H., et al. (2008). Drought meets acid: three new genera in a dothidealean clade of extremotolerant fungi. Stud. Mycol. 61, 1-20. doi: 10.3114/sim.2008.61.01

Shao, K., Gao, G., Qin, B., Tang, X., Wang, Y., Chi, K., et al. (2011). Comparing sediment bacterial communities in the macrophyte-dominated and algaedominated areas of eutrophic Lake Taihu, China. Can. J. Microbiol. 57, 263-272. doi: $10.1139 /$ w11-003

Singh, P., Roy, U., and Tsuji, M. (2016). Characterisation of yeast and filamentous fungi from Brøggerbreen glaciers, Svalbard. Polar Record. 52, 442-449. doi: $10.1017 / S 0032247416000085$

Singh, P., and Singh, S. M. (2012). Characterization of yeast and filamentous fungi isolated from cryoconite holes of Svalbard, Arctic. Polar Biol. 35, 575-583. doi: 10.1007/s00300-011-1103-1

Singh, P., Singh, S. M., Tsuji, M., Prasad, G. S., and Hoshino, T. (2014). Rhodotorula svalbardensis sp. nov., a novel yeast species isolated from cryoconite holes of Ny-Ålesund. Arct. Cryobiol. 68, 122-128. doi: 10.1016/j.cryobiol.2014.01.006

Sogonov, M. V., Schroers, H. J., Gams, W., Dijksterhuis, J., and Summerbell, R. C. (2005). The hyphomycete Teberdinia hygrophila gen. nov., sp. nov. and related anamorphs of Pseudeurotium species. Mycologia 97, 695-709. doi: 10.3852/ mycologia.97.3.695

Sonjak, S., Frisvad, J. C., and Gunde-Cimerman, N. (2006). Penicillium mycobiota in Arctic subglacial ice. Microb. Ecol. 52, 207-216. doi: 10.1007/s00248-0069086-0

Stibal, M., Box, J. E., Cameron, K. A., Langen, P. L., Yallop, M. L., Mottram, R. H., et al. (2017). Algae drive enhanced darkening of bare ice on the Greenland ice sheet. Geophys. Res. Lett. 44, 11463-11471. doi: 10.1002/2017GL0 75958

Stibal, M., Gözdereliler, E., Cameron, K. A., Box, J. E., Stevens, I. T., Gokul, J. K., et al. (2015). Microbial abundance in surface ice on the Greenland Ice Sheet. Front. Microbiol. 6:225. doi: 10.3389/fmicb.2015.00225

Tamura, K., Peterson, D., Peterson, N., Stecher, G., Nei, M., and Kumar, S. (2011). MEGA5: molecular evolutionary genetics analysis using maximum likelihood, evolutionary distance, and maximum parsimony methods. Mol. Biol. Evol. 28, 2731-2739. doi: 10.1093/molbev/msr121

Taylor, D. L., Walters, W. A., Lennon, N. J., Bochicchio, J., Krohn, A., Caporaso, J. G., et al. (2016). Accurate estimation of fungal diversity and abundance through improved lineage-specific primers optimized for Illumina amplicon sequencing. Appl. Environ. Microbiol. 82, 7217-7226. doi: 10.1128/AEM.02576-16

Tebo, B. M., Davis, R. E., Anitori, R. P., Connell, L. B., Schiffman, P., and Staudigel, H. (2015). Microbial communities in dark oligotrophic volcanic ice cave ecosystems of Mt. Erebus, Antarctica. Front. Microbiol. 6:179. doi: 10.3389/ fmicb.2015.00179

Tedersoo, L., Pärtel, K., Jairus, T., Gates, G., Põldmaa, K., and Tamm, H. (2009). Ascomycetes associated with ectomycorrhizas: molecular diversity and ecology with particular reference to the Helotiales. Environ. Microbiol. 11, 3166-3178. doi: $10.1111 /$ j.1462-2920.2009.02020.x 
Timling, I., and Taylor, D. L. (2012). Peeking through a frosty window: molecular insights into the ecology of Arctic soil fungi. Fungal Ecol. 5, 419-429. doi: 10.1016/j.funeco.2012.01.009

Timling, I., Walker, D. A., Nusbaum, C., Lennon, N. J., and Taylor, D. L. (2014). Rich and cold: diversity, distribution and drivers of fungal communities in patterned-ground ecosystems of the North American Arctic. Mol. Ecol. 23, 3258-3272. doi: 10.1111/mec. 12743

Turchetti, B., Buzzini, P., Goretti, M., Branda, E., Diolaiuti, G., D’Agata, C., et al. (2008). Psychrophilic yeasts in glacial environments of Alpine glaciers. FEMS Microbiol. Ecol. 63, 73-83. doi: 10.1111/j.1574-6941.2007. 00409.x

Turchetti, B., Hall, S. R., Connell, L. B., Branda, E., Buzzini, P., Theelen, B., et al. (2011). Psychrophilic yeasts from Antarctica and European glaciers: description of Glaciozyma gen. nov., Glaciozyma martinii sp. nov. and Glaciozyma watsonii sp. nov. Extremophiles 15, 573-586. doi: 10.1007/s00792-0110388-x

Turkiewicz, M., Pazgier, M., Kalinowska, H., and Bielecki, S. (2003). A coldadapted extracellular serine proteinase of the yeast Leucosporidium antarcticum. Extremophiles 7, 435-442. doi: 10.1007/s00792-003-0340-9

Uetake, J., Yoshimura, Y., Nagatsuka, N., and Kanda, H. (2012). Isolation of oligotrophic yeasts from supraglacial environments of different altitude on the Gulkana Glacier (Alaska). FEMS Microbiol. Ecol. 82, 279-286. doi: 10.1111/j. 1574-6941.2012.01323.x

van den Broeke, M., Box, J., Fettweis, X., Hanna, E., Noël, B., Tedesco, M., et al. (2017). Greenland ice sheet surface mass Loss: recent developments in observation and modeling. Curr. Clim. Change Rep. 3, 345-356. doi: 10.1007/ s40641-017-0084-8

van den Ende, A. H., and de Hoog, G. S. (1999). Variability and molecular diagnostics of the neurotropic species Cladophialophora bantiana. Stud. Mycol. $43,151-162$.

Walker, J. F., Aldrich-Wolfe, L., Riffel, A., Barbare, H., Simpson, N. B., Trowbridge, J., et al. (2011). Diverse Helotiales associated with the roots of three species of Arctic Ericaceae provide no evidence for host specificity. New Phytol. 191, 515-527. doi: 10.1111/j.1469-8137.2011.03703.x
White, T. J., Bruns, T., Lee, S. J., and Taylor, J. L. (1990). "Amplification and direct sequencing of fungal ribosomal RNA genes for phylogenetics," in PCR Protocols: a Guide to Methods and Applications, eds M. A. Innis, D. H. Gelfand, J. J. Sninsky, and T. J. White (London: Academic Press), 315-322. doi: 10.1016/ B978-0-12-372180-8.50042-1

Williamson, C. J., Anesio, A. M., Cook, J., Tedstone, A., Poniecka, E., Holland, A., et al. (2018). Ice algal bloom development on the surface of the Greenland Ice Sheet. FEMS Microbiol. Ecol. 94:fiy025. doi: 10.1093/femsec/fi y025

Yallop, M. L., Anesio, A. M., Perkins, R. G., Cook, J., Telling, J., Fagan, D., et al. (2012). Photophysiology and albedo-changing potential of the ice algal community on the surface of the Greenland ice sheet. ISME J. 6, 2302-2313. doi: 10.1038/ismej.2012.107

Zalar, P., Sonjak, S., and Gunde-Cimerman, N. (2012). "Fungi in polar environments," in Polar Microbiology: Life in a Deep Freeze, eds R. Miller and L. Whyte (Washington, DC: American Society of Microbiology Press), 79-94. doi: 10.1128/9781555817183.ch4

Zoller, S., and Lutzoni, F. (2003). Slow algae, fast fungi: exceptionally high nucleotide substitution rate differences between lichenized fungi Omphalina and their symbiotic green algae Coccomyxa. Mol. Phylogenet. Evol. 29, 629-640. doi: 10.1016/S1055-7903(03)00 215-X

Conflict of Interest Statement: The authors declare that the research was conducted in the absence of any commercial or financial relationships that could be construed as a potential conflict of interest.

Copyright (c) 2019 Perini, Gostinčar, Anesio, Williamson, Tranter and GundeCimerman. This is an open-access article distributed under the terms of the Creative Commons Attribution License (CC BY). The use, distribution or reproduction in other forums is permitted, provided the original author(s) and the copyright owner(s) are credited and that the original publication in this journal is cited, in accordance with accepted academic practice. No use, distribution or reproduction is permitted which does not comply with these terms. 